\title{
Effect of S-adenosylmethionine on Acetaminophen-induced Toxic Injury of Rat Hepatocytes in vitro
}

\author{
Halka Lotková, Otto Kučera, Tomáš Roušar, René Endlicher, Pavla Křiváková, \\ Tomáš Garnol, Zuzana Červinková
}

Department of Physiology, Faculty of Medicine in Hradec Králové, Charles University in Prague, Hradec Králové, Czech Republic

Received June 23, 2008

Accepted March 9, 2009

\begin{abstract}
Acetaminophen (AAP) overdose causes severe liver injury and is the leading cause of acute liver injury in humans. The mechanisms participating in its toxic effect are glutathione depletion, oxidative stress and mitochondrial dysfunction. S-adenosylmethionine (SAMe) is the principal biological methyl donor and is also a precursor of glutathione. In our previous studies we have documented a protective action of SAMe against various toxic injuries of rat hepatocytes in primary cultures. The aim of this study was to evaluate a possible protective effect of SAMe against AAP-induced toxic injury of primary rat hepatocytes. Hepatocytes were exposed to AAP $(2.5 \mathrm{mM})$ or AAP together with SAMe at the final concentrations of 5,25 or $50 \mathrm{mg} / 1$ for $24 \mathrm{~h}$. Incubation of hepatocytes with AAP caused a significant increase of the leakage of lactate dehydrogenase (LDH) $(p<0.001)$ and decline of the activity of cellular dehydrogenases (WST1) $(p<0.001)$. Co-incubation of hepatocytes with SAMe at any dose did not improve these markers of cellular integrity. The functional indicators improved in hepatocytes co-cultured with SAMe - urea production was significantly increased when using the highest dose of SAMe $(p<0.05)$; albumin synthesis was higher in all cultured hepatocytes exposed to SAMe $(p<0.05)$. SAMe did not influence AAP-induced decrease of cellular content of glutathione. Mitochondrial respiration of harvested digitonin-permeabilized hepatocytes was measured; Complex II was more sensitive to toxic action of AAP, respiration was decreased by $20 \%$. This decrease was completely abolished by SAMe.
\end{abstract}

Hepatotoxicity, hepatoprotective effect, mitochondrial membrane potential, urea, albumin, glutathione, $\mathrm{LDH}$

Acetaminophen (AAP) is a widely used, relatively safe analgesic/antipyretic drug. Nevertheless, AAP overdose causes centrilobular necrosis of the liver and is the leading cause of acute liver injury in humans in the United States and most of Europe (Lee 2007). The primary metabolic pathway for AAP is glucuronidation and sulphation in the liver; this yields relative non-toxic metabolites, which are excreted into bile (Mitchell et al. 1973). AAP hepatotoxicity is dependent on another metabolic pathway. The remaining part of AAP dose, which is not directly conjugated with the hydrophylic group, is biotransformed by the cytochrome P450 family to an electrophilic, highly reactive metabolite N-acetylp-benzoquinone imine (NAPQI), which is detoxified by glutathione (Jaeschke and Bajt 2006). However, if the formation of NAPQI exceeds the capacity of liver glutathione (GSH), this reactive metabolite forms covalent adducts primarily with cysteine residues on various cellular proteins (Nelson and Bruschi 2003; Allameh and Alikhani 2006). The most important mechanism of AAP-induced cell death seems to be a change in the function of critical cellular proteins due to covalent bindings. Numerous cytosolic, mitochondrial, ribosomal, microsomal, and nuclear proteins bound to AAP have been identified. Nevertheless, the primary cellular targets are mitochondrial proteins, with consequent impairment of mitochondrial respiration, increased production of reactive oxygen species, induction of lipid peroxidation, and onset of mitochondrial permeability transition. These changes lead to mitochondrial membrane depolarization, uncoupling of

Address for correspondence:

MUDr. Halka Lotková, Ph.D.

Department of Physiology, Medical Faculty in Hradec Králové

Charles University in Prague

Šimkova 870, 50038 Hradec Králové

Czech Republic

Phone: +420 495816435

Fax: +420495210 772

E-mail: lotko@lfhk.cuni.cz

http://www.vfu.cz/acta-vet/actavet.htm 
oxidative phosphorylation, release of mitochondrial ions and metabolites, and mitochondrial swelling (James et al. 2003). AAP is widely used as a model toxic agent to evaluate potential hepatoprotective effect of various substances.

S-adenosylmethionine (SAMe) is a naturally occurring substance produced from methionine and ATP in cytosol of all mammalian cells. This reaction is catalyzed by methionine adenosyltransferase (MAT). SAMe is the most important methyl donor, a fundamental intermediate in the transsulphuration pathway for the metabolism of methionine. This pathway is responsible for biosynthesis of numerous important substances, such as polyamines, cysteine, glutathione, and taurine (Mato et al. 1997). Consequently, SAMe is involved in the transmethylation and transsulphuration of the synthesis and metabolism of hormones, neurotransmitters, nucleic acids, phospholipids and proteins (Wu et al. 1996).

Exogenous administration of SAMe can protect against hepatocyte injury induced in vivo by agents including ethanol (Song et al. 2003), acetaminophen (Song et al. 2004), carbon tetrachloride (Corrales et al. 1992), and galactosamine (Stramentinoli et al. 1978). In our laboratory, we documented the protective effect of SAMe also in vitro on isolated hepatocytes after injury induced by D-galactosamine (Kučera et al. 2006), tertbutylhydroperoxide (Lotková et al. 2005), and thioacetamide (Lotková et al. 2007). The presumable mechanism by which SAMe protects hepatocytes from injury is associated with the role of SAMe in biosynthesis of glutathione (GSH), the main cellular antioxidant. Liver GSH can be reduced not only in response to oxidative stress but also due to the impairment of SAMe synthesis described after a toxic injury of the liver (Corrales et al. 1992). The depletion of liver GSH itself can lead to inactivation of MAT, the key enzyme in SAMe synthesis. Moreover, the decrease of GSH alleviated by SAMe was accompanied by attenuation of lipid peroxidation (Valentovic et al. 2004).

It was clearly documented that liver necrosis induced by AAP in the mouse was improved by SAMe (Bray et al. 1992; Valentovic et al. 2004) as evidenced by a reduction of AAPelevated activity of serum ALT and AST and from histological analysis. Nevertheless, there is a lack of data concerning the protective effect of SAMe against AAP hepatotoxicity in cell culture. The aim of the present study was to investigate the potential protective effect of SAMe on AAP-induced rat hepatocyte injury using primary culture.

\section{Materials and Methods}

\section{Chemicals}

Acetaminophen, type I collagen, trypan blue, rotenone, digitonin, respiratory substrates, ADP, 2,3-butandionmonoxime, thiosemicarbazide, urea, and all other chemicals, if not specified in the article, were obtained from Sigma-Aldrich (USA). William's E medium without phenol red, foetal bovine serum, penicillin, streptomycin and glutamine were purchased from PAN Biotech (Germany). Collagenase (Colagenasa cruda) was obtained from SEVAC (Czech Republic); S-adenosylmethionine (Transmetil) from Abbott (USA), insulin (Actrapid) from Hoechst (Germany); glucagon from Novo Nordisk (Denmark); prednisolon (Solu-Decortin) from Merck (Germany); the JC-1 fluorescent probe from Molecular Probes (Eugene, OR); Rat Albumin ELISA Quantification Kit from Bethyl Lab. Inc. (USA); Cell proliferation Reagent WST-1 from Roche (Germany), and the commercial kit for lactate dehydrogenase determination from Diagnostic Systems (Germany).

Animals

Male albino Wistar rats were obtained from BioTest (Konárovice, Czech Republic). Upon arrival, all animals were housed in quarantine for at least 7 days at $23 \pm 1{ }^{\circ} \mathrm{C}, 55 \pm 10 \%$ relative humidity, air exchange $12-14$ times/h, and 12-hour light-dark cycle periods (6:00 h to 18:00 h). Rats were provided tap water and fed standard laboratory rat chow DOS 2B (Velaz, Prague, Czech Republic) ad libitum. All animals received care according to the guidelines set by the institutional Animal Use and Care Committee of the Charles University, Prague, Czech Republic.

Hepatocyte Culture and Treatment

Hepatocytes were isolated from rats mentioned above with the body weight of 220-250 g by two-step collagenase perfusion (Berry et al. 1991). Their viability assessed by trypan blue exclusion was always greater than $90 \%$. Isolated cells were suspended in William's E medium supplemented with foetal bovine serum $(6 \%)$, glutamine $(2 \mathrm{mM})$, penicillin $(100 \mathrm{IU} / \mathrm{ml})$, streptomycin $(10 \mathrm{mg} / \mathrm{ml})$, insulin $(0.08 \mathrm{IU} / \mathrm{ml})$, prednisolon $(0.5 \mu \mathrm{g} / \mathrm{ml})$, and glucagon $(0.008 \mu \mathrm{g} / \mathrm{ml})$, then plated in collagen-coated Petri dishes $(60 \mathrm{~mm}$ diameter $)$ 
at a density of $2 \times 10^{6}$ cells/Petri dish. Hepatocytes were allowed to attach at $37{ }^{\circ} \mathrm{C}$ for $2 \mathrm{~h}$ in a gassed atmosphere $\left(5 \% \mathrm{CO}_{2}\right)$.

After the establishment of the monolayers, the medium was removed and replaced with fresh William's medium E, containing $2.5 \mathrm{mM}$ acetaminophen, or $2.5 \mathrm{mM}$ acetaminophen in combination with 5 , 25 or $50 \mathrm{mg} / 1 \mathrm{~S}$-adenosylmethionine. Control hepatocytes were incubated in William's medium E with no additions. The treatment period lasted $24 \mathrm{~h}$. At the end of the incubation period, the medium was collected for biochemical assays and cells were harvested for oxygraphic measurement or assessment of intracellular content of GSH.

Biochemical Assays

Hepatotoxicity of AAP was determined by the analysis of lactate dehydrogenase (LDH) activity in the culture medium and in hepatocytes and expressed as the ratio of LDH activity in the medium and LDH activity in hepatocytes (\% LDH leakage). Cell viability was also evaluated by WST-1 assay, which enables to measure the activity of intramitochondrial and extramitochondrial dehydrogenases. WST-1 assay was performed in collagencoated 96-well plates (density of $3 \times 10^{4}$ cells/well). Tetrazolium salts are cleaved by dehydrogenases of viable cells to produce formazan; the change of absorbance was detected spectrophotometrically using microtitre plate reader TECAN Infinite M200 (Austria) at the wavelength of $440 \mathrm{~nm}$. The functional capacity of hepatocytes was ascertained by determining the urea concentration in the culture medium using the diacetylmonoxime method (Wybenga et al. 1971), and by the amount of albumin secreted into the culture medium using commercial Rabbit anti Rat Albumin ELISA Quantitation kit from Bethyl Lab Inc. (USA).

After harvesting hepatocytes and cell lysis, antioxidative conditions within hepatocytes were determined by the measurement of glutathione content. Reduced form of glutathione (GSH) was analysed by reverse-phase high-performance liquid chromatography (Shimadzu, Japan), using a slightly modified method of Hissin and Hilf (1976) by Kand'ár et al. (2007). The separation was performed on reverse-phase column Discovery C18, $15 \mathrm{~cm} \times 4 \mathrm{~mm}, 5 \mu \mathrm{m}$ (Supelco, USA) followed by fluorimetric detection (excitation wavelength $350 \mathrm{~nm}$, emission wavelength $420 \mathrm{~nm}$ ). The CSW32 programme (DataApex, Czech Republic) was used for the collecting and processing of chromatographic data.

Mitochondrial membrane potential

The changes in mitochondrial membrane potential $(\Delta \psi)$ in hepatocytes was detected by the fluorescent probe, 5,5',6,6'-tetrachloro-1,1',3,3'-tetraethyl-benzimidazolcarbocyanine iodide, known as JC-1 (Salvioli et al. 1997). This cationic dye exhibits potential-dependent accumulation in mitochondria, indicated by a fluorescence emission shift from green (monomer dye) to red (J-aggregate day). Hepatocytes plated in collagen-coated 96-well plates $\left(3 \times 10^{4}\right.$ cells/well) were preloaded with $10 \mu \mathrm{g} / \mathrm{ml} \mathrm{JC}-1$ dissolved in Krebs-Henseleit solution for $30 \mathrm{~min}$ $\left(37^{\circ} \mathrm{C}, 5 \% \mathrm{CO}_{2} / 95 \%\right.$ air). Then the hepatocytes were washed three times with Krebs-Henseleit solution. TECAN Infinite M200 plate reader (excitation wavelength $485 \mathrm{~nm}$ ) was used to measure fluorescence intensities for the aggregated JC-1 (emission wavelength $580 \mathrm{~nm}$ ).

Measurement of oxygen uptake by hepatocytes (High-Resolution Respirometry)

Oxygen consumption was measured by the High-Resolution Oxygraph 2K (Oroboros, Austria). Hepatocytes were harvested using collagenase $(1 \mathrm{mg} / \mathrm{ml})$. Measurements were done in $2 \mathrm{ml}$ of incubation medium at $30^{\circ} \mathrm{C}$. Digitonin-permeabilised hepatocytes were incubated in K-medium, which contained $100 \mathrm{mM}$ potassium chloride, $10 \mathrm{mM}$ Tris $\mathrm{HCl}, 4 \mathrm{mM}$ potassium phosphate (dibasic), $3 \mathrm{mM}$ magnesium chloride, and $1 \mathrm{mM}$ EDTA (at pH 7.4). Oroboros software (DatLab 4.1) was used for the evaluation of oxygen uptake. Oxygen uptake curves are presented as the first derivation of oxygen tension changes.

Statistical analysis

All values are expressed as means \pm SD. One-way ANOVA was used to determine significance. TukeyKramer's post-hoc test was used for multiple comparisons between groups (Prism 4 for Windows, GraphPad Software, USA). Significance is indicated in the figures by $p^{*}<0.05 ; p * *<0.01 ; p * * *<0.001$, respectively.

\section{Results}

\section{Effect of SAMe against AAP-induced hepatotoxicity}

The AAP-induced toxic effect in hepatocyte cultures was investigated by measuring LDH activity in the culture medium and in hepatocytes, expressed as LDH leakage (Fig. 1). Incubation with AAP alone caused a significant increase in LDH leakage in comparison with the control group $(p<0.001)$. SAMe at any concentration did not decrease LDH leakage; the values were similar to those in the group incubated with AAP alone.

Similar results were observed also, when cell viability in cultures was evaluated by WST-1 assay (Fig. 2). Exposure to AAP alone induced a significant decrease of the activity of cell dehydrogenases to $56 \%$ of controls $(p<0.001)$. We did not observe any protective effect of SAMe against AAP-induced decline of the activity of dehydrogenases. 


\section{LDH leakage}

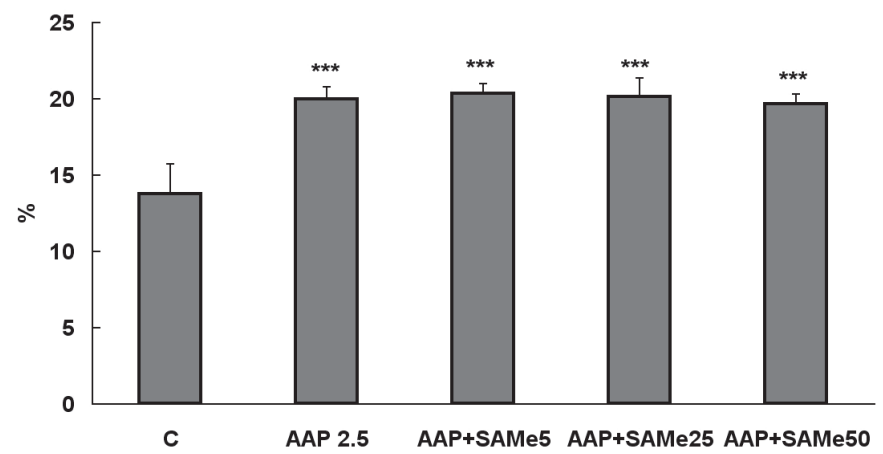

Fig. 1. LDH leakage after 24-hour incubation with William's E medium (C - controls), with acetaminophen at the concentration of $2.5 \mathrm{mM}$ (AAP 2.5) or acetaminophen and S-adenosylmethionine at the concentration of 5, 25 and $50 \mathrm{mg} / \mathrm{l}$, respectively (AAP+SAMe 5, 25, and 50, respectively). Data are expressed as mean value $\pm \operatorname{SD}(\mathrm{n}=6)$. $* * *=p<0.001$ compared to controls

\section{WST-1}

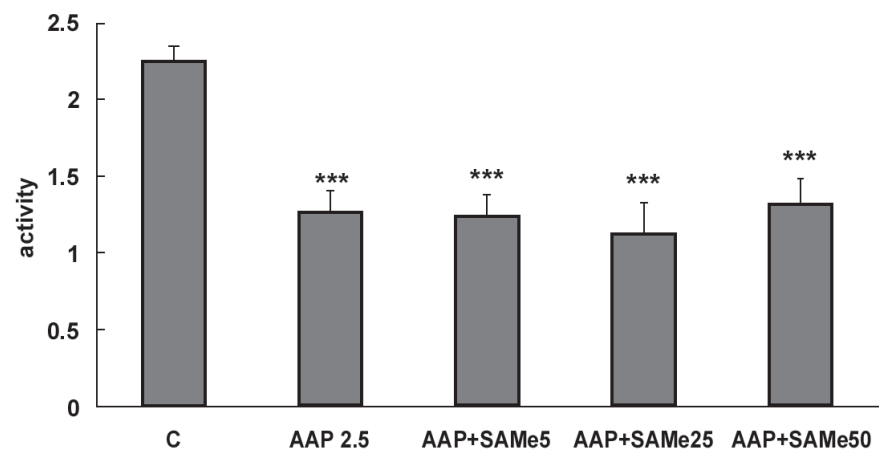

Fig. 2. WST-1 assay - activity of intracellular dehydrogenases after 24-hour incubation with William's E medium (C - controls), with acetaminophen at the concentration of $2.5 \mathrm{mM}$ (AAP 2.5) or acetaminophen and S-adenosylmethionine at the concentration of 5,25 and $50 \mathrm{mg} / 1$, respectively (AAP+SAMe 5,25 , and 50 , respectively). Data are expressed as mean value $\pm \mathrm{SD}(\mathrm{n}=8)$.

$* * *=p<0.001$ compared to controls

Effect of SAMe on AAP-induced changes in urea and albumin synthesis

Urea concentration (Fig. 3), a marker of functional capacity of hepatocytes, was slightly but not significantly decreased in hepatocyte cultures incubated with AAP alone at $24 \mathrm{~h}$ incubation period. Treatment with SAMe at the dose of $50 \mathrm{mg} / \mathrm{l}$ only prevented AAP-induced decrease of urea concentration in cultivation medium $(p<0.01)$. Fig. 4 documents that incubation with AAP alone caused a significant decrease of albumin concentration in the media, another important marker of the functional capacity of hepatocytes, in comparison with controls $(p<0.05)$. SAMe at all the doses prevented AAP-induced decrease in albumin production $(p<0.05)$.

Effect of SAMe on AAP-induced decrease of intracellular glutathione content

Fig. 5 shows that GSH content significantly decreased after incubation with AAP in 


\section{Urea synthesis}

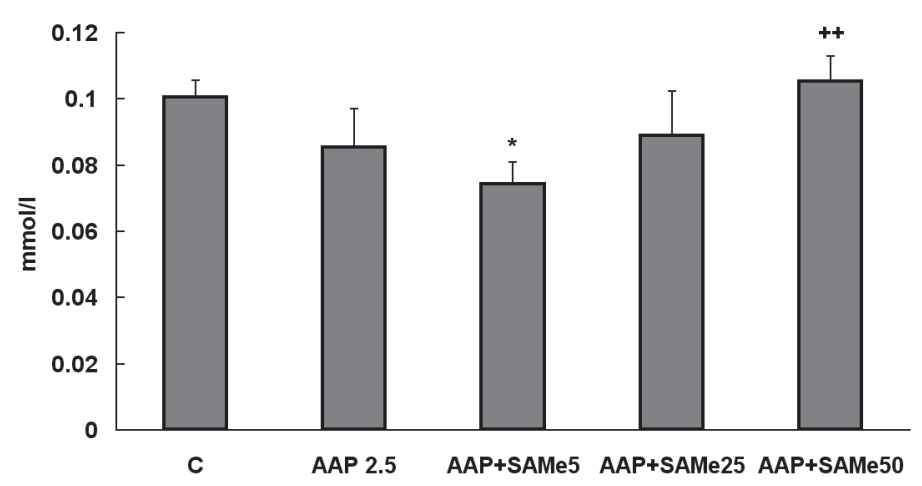

Fig. 3. Urea synthesis - Production of urea by hepatocytes incubated with William's E medium (C - controls), with acetaminophen at concentration of $2.5 \mathrm{mM}$ (AAP 2.5) or acetaminophen and S-adenosylmethionine at concentration of

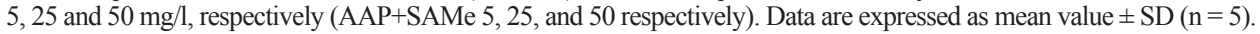
$*=p<0.05$ compared to controls; ${ }^{++}=p<0.01$ compared to the group incubated with AAP alone

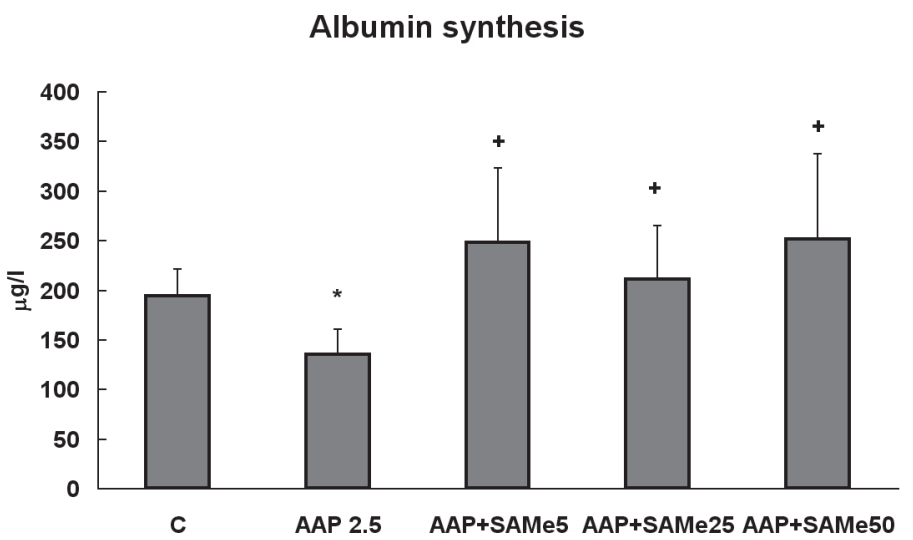

Fig. 4. Albumin synthesis - Production of albumin by hepatocytes incubated with William's E medium (C controls), with acetaminophen at concentration of $2.5 \mathrm{mM}$ (AAP 2.5) or acetaminophen and S-adenosylmethionine at concentration of 5, 25 and $50 \mathrm{mg} / \mathrm{l}$, respectively (AAP+SAMe 5, 25, 50 respectively). Data are expressed as mean value $\pm \mathrm{SD}(\mathrm{n}=5)$.

$*=p<0.05$ compared to controls; ${ }^{+}=p<0.05$ compared to the group incubated with AAP alone

comparison with control group $(p<0.001)$. Glutathione depletion was not prevented by treatment with SAMe.

Effect of SAMe on AAP-induced decrease in the mitochondrial membrane potential

Changes of mitochondrial membrane potential were measured using the JC-1 fluorescence probe, which changes emission wavelength in response to decreasing membrane potential. Fig. 6 depicts JC-1 fluorescence at $580 \mathrm{~nm}$ (excitation wavelength $485 \mathrm{~nm}$ ) expressed as $\%$ of controls. Neither AAP alone nor AAP in combination with SAMe exerted significant alteration of fluorescence, although a tendency to decrease of mitochondrial membrane potential is apparent. 


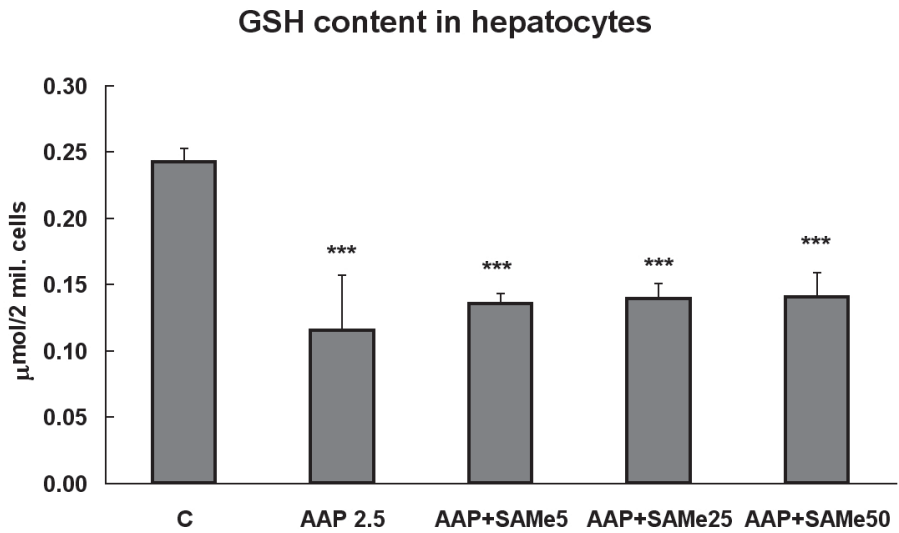

Fig. 5. Intracellular content of GSH in hepatocytes incubated with William's E medium (C - controls), with acetaminophen at concentration of $2.5 \mathrm{mM}$ (AAP 2.5) or acetaminophen and S-adenosylmethionine at concentration of 5, 25 and $50 \mathrm{mg} / \mathrm{l}$, respectively (AAP+SAMe 5, 25, and 50, respectively). Data are expressed as mean value $\pm \mathrm{SD}(\mathrm{n}=5)$.

$* * *=p<0.001$ compared to controls

\section{$\mathrm{JC}-1$ fluorescence at $580 \mathrm{~nm}$}

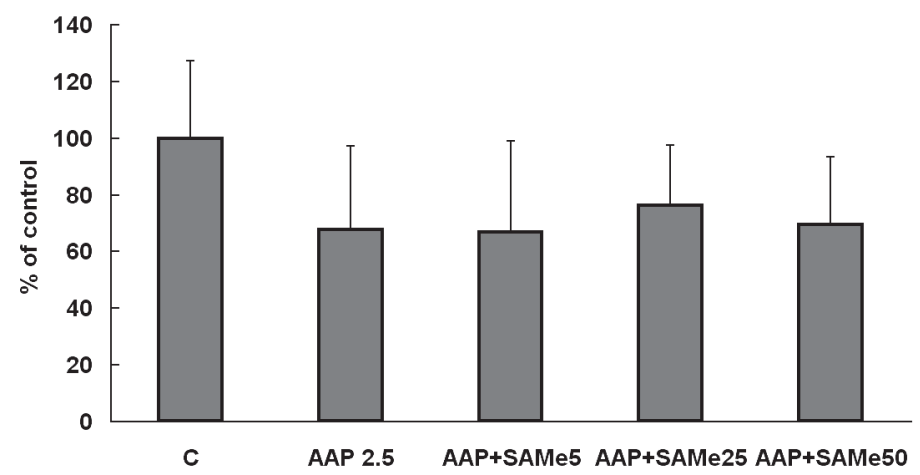

Fig. 6. Fluorescence at $580 \mathrm{~nm}$ of fluorescent dye JC-1 accumulated in hepatocytes incubated with William's E medium (C - controls), with acetaminophen at concentration of $2.5 \mathrm{mM}$ (AAP 2.5) or acetaminophen and $\mathrm{S}$-adenosylmethionine at concentration of 5,25 and $50 \mathrm{mg} / 1$, respectively (AAP+SAMe 5, 25, and 50 respectively). Data are expressed as mean value $\pm \mathrm{SD}(\mathrm{n}=8)$.

\section{Effect of SAMe on AAP-induced changes in respiration of glutamate +} malate and succinate

Respiratory rates of NADH-dependent (glutamate + malate) and flavoprotein-dependent (succinate) substrates were tested in hepatocytes harvested after $24 \mathrm{~h}$ incubation with complete William's E medium (Fig. 7a), with AAP at concentration of $2.5 \mathrm{mM}$ (Fig. 7b) or AAP and SAMe at concentration of $25 \mathrm{mg} / \mathrm{l}$ (Fig. 7c). Measurement was performed using high-resolution respirometry on digitonin-permeabilised hepatocytes incubated in K-medium. Specific substrates were added in sequence into the measuring chamber. First, we measured the activity of Complex I by addition of glutamate + malate and ADP, after which Complex I was inhibited by the addition of rotenone. We then measured activity of Complex II by subsequent addition of succinate. The results are presented as the outcome of 


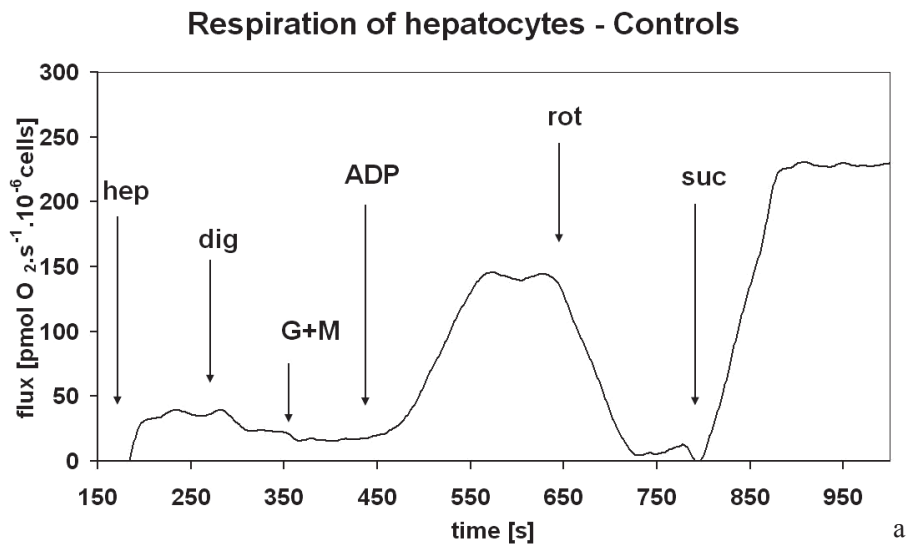

Respiration of hepatocytes $-2.5 \mathrm{mM}$ AAP

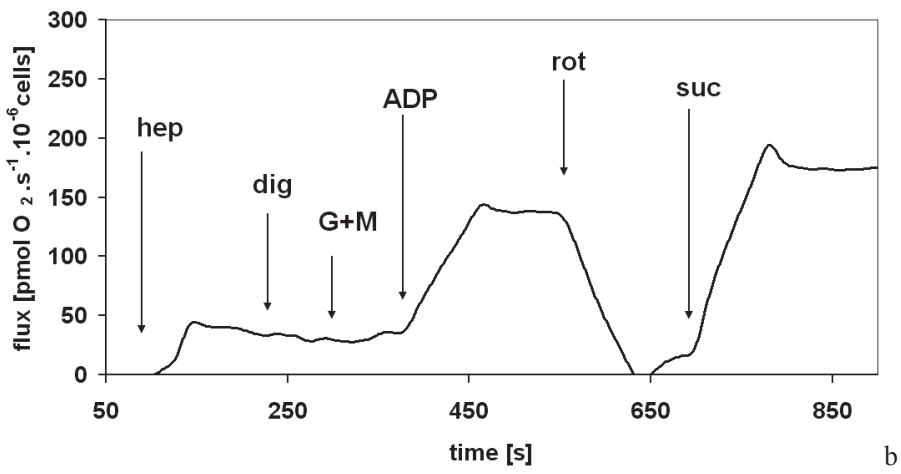

Respiration of hepatocytes - AAP+SAMe25

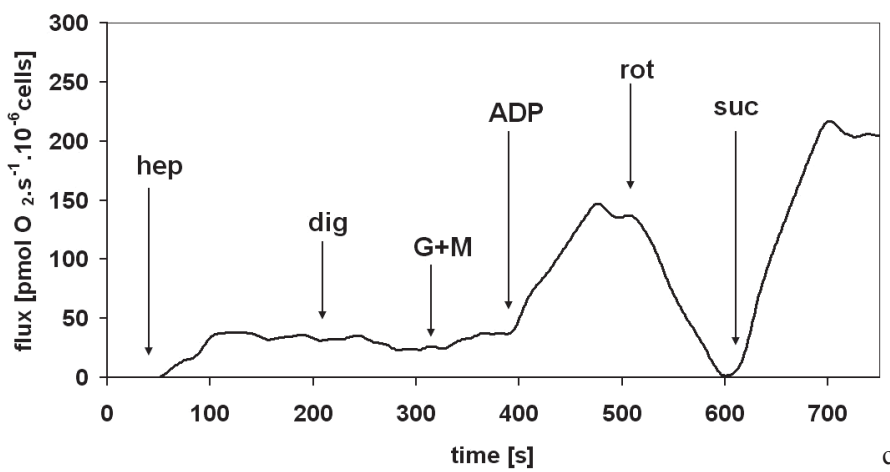

Fig. 7a, 7b, 7c. Respiration of hepatocytes harvested after $24 \mathrm{~h}$ incubation with William's E medium (Fig. 7a), with acetaminophen at the concentration of $2.5 \mathrm{mM}$ (Fig. 7b) or acetaminophen and S-adenosylmethionine at the concentration of $25 \mathrm{mg} / 1$ (Fig. 7c).

Hepatocytes were incubated in K-medium. The arrows indicate the successive addition of hepatocytes (hep), 20 $\mathrm{mg} / \mathrm{ml}$ digitonin $(\mathrm{dig}), 10 \mathrm{mM}$ glutamate $+2.5 \mathrm{mM}$ malate $(\mathrm{G}+\mathrm{M}), 1 \mathrm{mM}$ ADP, $1 \mu \mathrm{M}$ rotenone (rot) and $10 \mathrm{mM}$ succinate (suc). 
a typical experiment. Nevertheless, we had very reproducible results throughout this study. Our data show that oxidation of NADH-dependent substrates was not altered in hepatocyte cultures treated with AAP in comparison with controls. While oxidation of flavoproteindependent substrates is more sensitive to AAP-induced damage, respiration was decreased by $20 \%$ in comparison with controls. This decrease was partly reduced by SAMe at a dose of $25 \mathrm{mg} / \mathrm{l}$, and completely abolished by SAMe at a dose of $50 \mathrm{mg} / \mathrm{l}$ (Fig. 8).

\section{Activity of Respiratory Complex I and II}

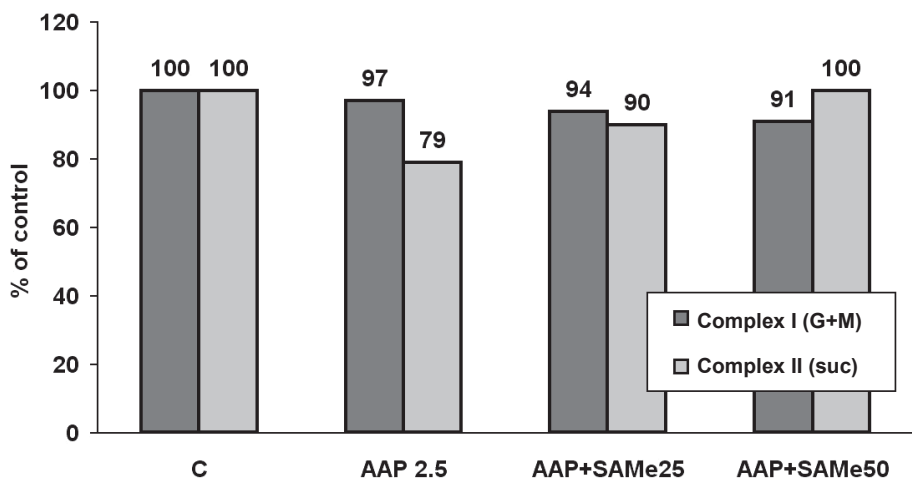

Fig. 8. Activity of respiratory complexes I and II of rat hepatocytes harvested after $24 \mathrm{~h}$ incubation with William's E medium (C), with acetaminophen at concentration of $2.5 \mathrm{mM}$ (AAP 2.5) or acetaminophen and $\mathrm{S}$-adenosylmethionine at the concentration of $25 \mathrm{mg} / 1$ and $50 \mathrm{mg} / 1$, respectively (AAP+SAMe25, AAP+SAMe50). Data are expressed as \% of the activity of complex I and II in controls

\section{Discussion}

Acetaminophen hepatotoxicity is the leading cause of drug-induced acute liver failure. The only drug used for treatment of AAP overdose in clinical practice is $\mathrm{N}$-acetylcystein (NAC), a precursor of cysteine and GSH, respectively. NAC is able to prevent completely AAP-induced injury in mouse hepatocytes (Bajt et al. 2004). The other precursor molecule of cysteine is SAMe. SAMe is a naturally occurring substance utilized by three key metabolic pathways - transmethylation, transsulphuration and polyamine synthesis.

In our experiments AAP at a concentration of $2.5 \mathrm{mmol} / \mathrm{l}$ induced toxic injury to rat hepatocytes in vitro characterised by LDH leakage corresponding with plasma membrane damage (Fig. 1), and decrease in cellular dehydrogenases activities, measured using WST1 test (Fig. 2). Urea synthesis was not affected by 24-hour incubation with $2.5 \mathrm{mM}$ AAP. This is consistent with our previous findings that urea synthesis is not altered up to $24 \mathrm{~h}$ cultivation neither with D-galactosamine (Kučera et al. 2006) or thioacetamide (Lotková et al. 2007). On the contrary, albumin production was more sensitive to AAP injury to hepatocytes. We found a significant change in albumin synthesis that was decreased by $30 \%$ (Fig. 4) in comparison with controls.

According to literature data the main cause of hepatocyte injury in AAP overdose is the formation of a highly reactive metabolite NAPQI. Although a number of P450 enzymes can metabolize AAP, the most relevant isoenzyme is CYP2E1 (Jaeschke and Bajt 2006). NAPQI is detoxified by GSH, which leads to GSH depletion in the liver. In the absence of GSH, NAPQI is bound to intracellular proteins. In our experiments AAP at a concentration of $2.5 \mathrm{mM}$ decreased the intracellular content of glutathione to less than $50 \%$ of controls (Fig. 5). It was thought that exogenously administered SAMe is able to enter cells and participate in the described metabolic pathways. Contrary to that, it was 
documented that SAMe salts cannot easily enter into mammalian cells at least at lower concentrations (Bontemps and van Den Berghe 1997). This corresponds with our results that SAMe at any used concentration did not increase GSH content in hepatocytes exposed to acetaminophen. Bontemps and Den Berghe (1977) suggest that SAMe does not penetrate hepatocytes significantly but is utilized for phospholipid methylation on outer surface of the plasma membrane. Nevertheless, SAMe in our experiments did not affect LDH leakage. We previously reported that incubation of hepatocyte culture only with SAMe in medium at the concentration of $10 \mathrm{mg} / 1$ and higher for $30 \mathrm{~min}$ had caused an increase in GSH cellular content (Lotková et al. 2005). With respect to our finding, we could assume intracellular GSH produced by hepatocytes during the treatment with SAMe and AAP is oxidized when NAPQI is detoxified and GSSG releases the cell into medium.

Mitochondria have been documented to play an important role in the AAP-induced liver injury (Vendemiale et al. 1996; Burcham and Harman 1991; Masubuchi et al. 2005). Oxidative stress promotes MPT (Reid et al. 2005) characterised by a decrease of mitochondrial membrane potential (MMP). Moreover, it is presumed that the superoxide generation resulted from mitochondrial permeability transition (MPT), an abrupt increase in the permeability of inner mitochondrial membrane to ions and small molecular weight solutes (Jaeschke et al. 2003). AAP in our experimental arrangement did not cause a significant decline of MMP measured using fluorescent probe JC-1 (Fig. 6). This finding is discordant with data published by Reid et al. (2005). They described a significant decrease of MMP in mice hepatocytes cultivated with $1 \mathrm{mM}$ AAP for $5 \mathrm{~h}$. With respect to that, the mice hepatocytes are more sensitive to AAP, the decline of GSH content in our experiment was probably not sufficiently high to induce mitochondrial injury. Partial recovery of oxidative stress during the 24-h incubation with AAP may also be taken into consideration. Changes in cell energy metabolism and mitochondrial dysfunction have been observed after acetaminophen administration. The influence of AAP on respiration probably depends on AAP concentration and on the time of exposure (Vendemiale et al. 1996). Our results suggest that AAP inhibits mitochondrial respiration by site-specific manner. Respiration stimulated by succinate and ADP (respiratory state 3 ) reflecting the activity of respiratory Complex II in digiton-permeabilized rat hepatocytes was more sensitive to AAP, than respiration activated by $\mathrm{NADH}$-linked substrates (glutamate+malate and ADP, state 3 ) accordant with the activity of respiratory Complex I. These findings are in agreement with experiments that examined the effect of NAPQI - reactive metabolite of acetaminophen on respiration in isolated mitochondria (Burcham and Harman 1991) from mouse hepatocytes. Interestingly, the model prooxidant agent, tert-butylhydroperoxide, exerts the opposite effect than acetaminophen; it inhibits the activity of respiratory Complex I to higher extent than the activity of respiratory Complex II (Drahota et al. 2005). NAPQI may probably directly interact with sulphhydryl groups present on succinate dehydrogenase and thus induce the loss of enzyme activity. The respiratory Complex I could be impaired indirectly by increased oxidative stress induced by AAP administration. Thus in our experimental conditions the higher sensitivity of Complex II to AAP seems to be caused by direct interaction of NAPQI with succinate dehydrogenase while activity of Complex I was not influenced by AAP. SAMe completely abolished the AAP-induced decrease of Complex II activity, this could be explained by the fact that SAMe is weak inhibitor of CYP2E1 (Caro and Cederbaum 2005). Further experiments with different AAP doses and cultivation times are required for precise explanation of these observations.

\section{Účinek S-adenosylmethioninu na acetaminofenem navozené toxické poškození hepatocytů potkana $\mathrm{v}$ in vitro podmínkách}

Předávkování acetaminofenem (AAP) může vést $\mathrm{k}$ těžkému jaternímu poškození a je jednou z hlavních př́ičin jaterního selhání. Mechanizmy, které se podílejí na tomto to- 
xickém účinku, jsou deplece glutathionu, oxidativní stress a poškození mitochondrií. S-adenosylmethionin (SAMe) je hlavním donorem methylové skupiny a také prekurzorem glutathionu. V našich předchozích studiích jsme potvrdili protektivní účinek SAMe na hepatocyty toxicky poškozené v primární kultuře. Cílem této práce bylo ověření protektivního účinku SAMe na hepatocyty poškozené acetaminofenem. Primární kultura hepatocytů byla inkubována s AAP (2,5 mM) nebo s AAP dohromady se SAMe v koncentraci 5, 25 nebo $50 \mathrm{mg} / 1$ po dobu $24 \mathrm{~h}$. Inkubace hepatocytů s AAP vedla $\mathrm{k}$ signifikantnímu zvýšení úniku LDH z hepatocytů $(p<0,001)$ a poklesu aktivity buněčných dehydrogenáz - WST-1 $(p<0,001)$. Současná inkubace hepatocytů se SAMe nevedla ke zlepšení buněčné integrity. Učinkem SAMe se zlepšily hodnoty funkčních ukazatelů - produkce močoviny signifikantně vzrostla při použití nejvyšší dávky $\operatorname{SAMe}(p<0,05)$; syntéza albuminu se zvýšila účinkem všech testovaných koncentrací SAMe $(p<0,05)$. Kultivace se SAMe nevedla ke zmírnění poklesu obsahu GSH navozeného AAP. Při měření respirace mitochondrií byla zjištěna vyšší citlivost k toxickým účinkům AAP u komplexu II, respirace klesla o $20 \%$. Tento pokles byl zmírněn účinkem SAMe.

\section{Acknowledgement}

This work was supported by grant MSM 0021620820.

\section{References:}

Allameh A, Alikhani N 2002: Acetaminophen-glutathione conjugate formation in a coupled cytochrome P-450glutathione S-transferase assay system mediated by subcellular preparation from adult and weanling rat tissues. Toxicol in Vitro 16: 637-641

Bajt ML, Knight TR, Lemasters JJ, Jaeschke H 2004: Acetaminophen-induced oxidant stress and cell injury in cultured mouse hepatocytes: protection by N-acetyl cysteine. Toxicol Sci 80: 343-349

Berry MN, Edwards AM, Barritt GJ 1991: Isolated hepatocytes; preparation, properties and applications. In: Burdon RH, Van Knippenberg PH (Ed): Laboratory techniques in biochemistry and molecular biology, vol. 21. Elsevier Science Publisher B.V., Amsterdam, pp. 1-49

Bontemps F, Van Den Berghe G 1997: Metabolism of exogenous S-adenosylmethionine in isolated rat hepatocyte suspensions: methylation of plasma-membrane phospholipids without intracellular uptake. Biochem J 327: 383-389

Bray GP, Tredger JM, Williams R 1992: S-Adenosylmethionine protects against acetaminophen hepatotoxicity in two mouse models. Hepatology 15: 297-301

Burcham PC, Harman AW 1991: Acetaminophen toxicity results in site-specific mitochondrial damage in isolated mouse hepatocytes. J Biol Chem 266: 5049-5054

Caro AA, Cederbaum AI 2005: Inhibition of CYP2E1 catalytic activity in vitro by S-adenosyl-L-methionine. Biochem Pharmacol 69: 1081-1093

Corrales F, Giménez A, Alvarez L, Caballería J, Pajares MA, Andreu H, Parés A, Mato JM, Rodés J 1992: S-adenosylmethionine treatment prevents carbon tetrachloride-induced S-adenosylmethionine synthetase inactivation and attenuates liver injury. Hepatology 16: 1022-1027

Drahota Z, Křiváková P, Červinková Z, Kmoníčková E, Lotková H, Kučera O, Houštěk J 2005: Tert-butyl hydroperoxide selectively inhibits mitochondrial respiratory-chain enzymes in isolated rat hepatocytes. Physiol Res 54: 67-72

Hissin PJ, Hilf R 1976: A fluorometric method for determination of oxidized and reduced glutathione in tissues. Anal Biochem 74: 214-226

Jaeschke H, Bajt ML 2006: Intracellular signalling mechanisms of acetaminophen-induced liver cell death. Toxicol Sci 89: 31-41

Jaeschke H, Knight TR, Bajt ML 2003: The role of oxidant stress and reactive nitrogen species in acetaminophen hepatotoxicity. Toxicol Lett 144: 279-288

James LP, Mayeux PR, Hinson JA 2003 : Acetaminophen-induced hepatotoxicity. Drug Metab Dispos 31: 14991506

Kand'ár R, Žáková P, Lotková H, Kučera O, Červinková Z 2007: Determination of reduced and oxidized glutathione in biological samples using liquid chromatography with fluorimetric detection. J Pharmaceut Biomed 12: 1382-1387

Kučera O, Červinková Z, Lotková H, Křiváková, P, Roušar T, Mužáková V, Héžová R, Kand'ár R, Rudolf E 2006: Protective effect of S-adenosylmethionine against D-galactosamine-induced injury of rat hepatocytes in primary culture. Physiol Res 55: 551-560

Lee WM 2007: Acetaminophen toxicity: changing perceptions on a social/medical issue. Hepatology 46: 966-970 
Lotková H, Červinková Z, Kučera O, Křiváková P, Kand'ár R 2005: Protective effect of S-adenosylmethionine on celular and mitochondrial membranes of rat hepatocytes against tert-butylhydroperoxide-induced injury in primary culture. Chem Biol Inter 156: 13 - 23

Lotková H, Červinková Z, Kučera O, Roušar T, Křiváková P 2007: S-adenosylmethionine exerts a protective effect against thioacetamide-induced injury in primary cultures of rat hepatocytes. ATLA 35: $363-371$

Masubuchi Y, Suda C, Horie T 2005: Involvement of mitochondrial permeability transition in acetaminopheninduced liver injury in mice. J Hepatol 42: 110-116

Mato JM, Alvarez L, Ortiz P, Pajeras MA 1997: S-adenosylmethionine synthesis: molecular mechanisms and clinical implications. Pharmacol Therapeut 73: 265-280

Mitchell JR, Jollow DJ, Potter WZ, Davis DC, Gillette JR, Brodie BB 1973: Acetaminophen-induced hepatic necrosis. I. Role of dug metabolism. J Pharmacol Exp Ther 187: 185-194

Nelson SD, Bruschi SA 2003: Mechanisms of acetaminophen-induced liver diseases. In: Kaplowitz N, DeLeve LD (Ed): Drug induced liver disease. Marcel Dekker, Inc., New York, 287-325 pp.

Reid AB, Kurten RC, McCullough SS, Brock RW, Hinson JA 2005: Mechanisms of acetaminophen-induced hepatotoxicity: role of oxidative stress and mitochondrial permeability transition in freshly isolated mouse hepatocytes. J Pharmacol Exp Ther 312: 509-516

Salvioli S, Ardizzoni A, Franceschi C, Cossarizza A 1997: JC-1, but not DiOC 6 (3) or rhodamine 123, is a reliable fluorescent probe to assess $\Delta \psi$ changes in intact cells: implications for studies on mitochondrial functionality during apoptosis. FEBS Lett 411: 77-82

Song Z, Zhou Z, Chen T, Hill D, Kang J, Barve S, McClain C 2003: S-adenosylmethionine (SAMe) protects against acute alcohol induced hepatotoxicity in mice. J Nutr Biochem 14: 591-597

Song Z, McClain CJ, Chen T 2004: S-adenosylmethionine protects against acetaminophen-induced hepatotoxicity in mice. Pharmacology 71: 199-208

Stramentinoli G, Gualano M, Ideo G 1978: Protective role of S-adenosyl-L-methionine on liver injury induced by D-galactosamine in rats. Biochem Pharmacol 27: 1431-1433

Valentovic M, Terneus M, Harmon RC, Carpenter AB 2004: S-adenosylmethionine (SAMe) attenuates acetaminophen hepatotoxicity in C57BL/6 mice. Toxicol Lett 154: 165-174

Vendemiale G, Grattagliano I, Altomare E, Turturro N, Guerrieri F 1996: Effect of acetaminophen administration on hepatic glutathione compartmentation and mitochondrial energy metabolism in the rat. Biochem Pharmacol 52: $1147-54$

Wu J, Söderbergh H, Karlsson K, Danielsson A 1996: Protective effect of S-adenosyl-L-methionine on bromobenzene and D-galactosamine-induced toxicity to isolated rat hepatocytes. Hepatology 23: 359 - 365

Wybenga DR, Di Gorgio J, Pileggi VJ 1971: Manual and automated methods for urea nitrogen measurement in whole serum. Clin Chem 17: 891-895 
